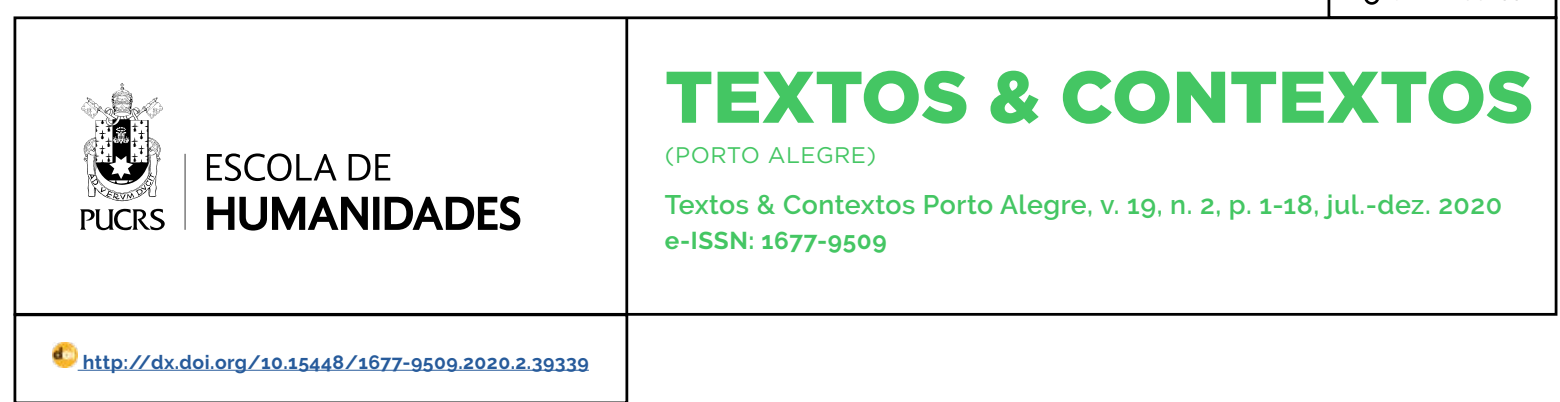

HOMENAGEM ESPECIAL

\title{
Entrevista com Jorge Gilberto Krug
}

Suéllen Bezerra Alves

\section{Keller ${ }^{1}$}

orcid.org/0000-0003-2390-9519

suellenbezerra@live.com

Recebido em: 12/10/2020

Aprovado em: 5/11/2020.

Publicado em: 23/12/2020.

\section{(c) (1)}

Artigo está licenciado sob forma de uma licença Creative Commons Atribuição 4.0 Internacional.
Jorge Gilberto Krug foi um dos protagonistas na história do Serviço Social no Rio Grande do Sul e no Brasil, deixando um importante legado no âmbito da renovação da profissão no contexto latino-americano. Jorge foi assistente social em instituições estaduais e docente na Universidade de Caxias do Sul (UCS) e Universidade Luterana do Brasil (ULBRA), tendo publicado artigos e livros, contribuindo, dentre outras temáticas, para a teoria do Desenvolvimento de Comunidade. Foi dirigente de entidades da categoria, cabendo citar sua passagem como presidente, tanto do Conselho Federal de Assistentes Sociais (CFAS), atual Conselho Federal de Serviço Social (CFESS), de 1980 a 1983, como do Conselho Regional de Serviço Social do Rio Grande do Sul em dois mandatos, de 1972 a 1975 e 1975 a 1978.

Recentemente, Jorge contribuiu em projetos sobre a memória histórica da profissão no Rio Grande do Sul, Brasil e América Latina, com destaque à participação no projeto "Serviço Social, memórias e resistência contra a ditadura", quando revelou de que forma, ao lado de outros(as) assistentes sociais, fizeram enfrentamento ao periodo ditatorial militar (1964-1985). Trazendo concretude ao passado profissional, Jorge não se esquivava em participar de eventos e pesquisas, compartilhando com entusiasmo o arcabouço de vivências que contribuiram para a reconceituação do Serviço Social. No dia 13 de setembro de 2020 nos despedimos de Jorge, aos 80 anos de idade, momento em que várias entidades profissionais manifestaram pesar pelo seu falecimento.

A presente entrevista constitui uma dessas muitas contribuições ao Serviço Social brasileiro, realizada no dia 21 de dezembro de 2017, durante cerca de quatro horas. O propósito, naquele momento, era reunir material empírico para a pesquisa de doutoramento em Serviço Social pela Pontifícia Universidade Católica do Rio Grande do Sul (PUCRS), com a anuência do entrevistado para possivel divulgação de sua identidade, a qual não foi revelada na redação da tese. Entrevistei-o na Biblioteca Central Irmão José Otão, da PUCRS, instituição que acolheu Jorge como estudante de graduação, especialização e mestrado entre 1963 e 1981, e ainda como professor visitante em 2004.

Destaco que Krug esteve presente, no dia 22 de março de 2019, na defesa da tese intitulada "A ascensão do conservadorismo e o esgotamento 
do projeto neodesenvolvimentista: implicações profissionais ao Serviço Social", a qual contou com a sua entrevista. Na ocasião, levou suas contribuições e críticas anotadas à mão, denotando seu perseverante compromisso com a produção de conhecimento, bem como com os rumos da profissão na atual conjuntura. Suprimindo as divergências teórico-políticas entre entrevistadora e entrevistado, muitos de seus apontamentos foram considerados e incorporados ao texto, que posteriormente veio a se transformar no livro $A$ Ofensiva do Conservadorismo: Serviço Social em Tempos de Crise, publicado em 2019

Registro que a edição das quase quarenta páginas de transcrição foi realizada com admiração e estima, constituindo um trabalho árduo selecionar os principais excertos que integram a entrevista. Essa contempla tanto as experiências profissionais em âmbito nacional e internacional, quanto a sua percepção sobre o Serviço Social, o papel da universidade e a conjuntura contemporânea. Foram abordados temas polêmicos, sendo que as respostas do entrevistado revelam a formação em dado tempo histórico. A publicação dessa conversa se insere no quadro de homenagens às contribuições de Jorge Gilberto Krug ao Serviço Social brasileiro, publicizando os relatos acerca da sua impar trajetória, os quais revelam também parte da sua personalidade, carregada de disposição e bom humor.

Jorge, a pesquisa consiste numa investigação de como a profissão está se conformando nesse momento histórico de esgotamento do periodo que alguns autores vêm chamando de "neodesenvolvimentismo", em concomitância ao avanço do conservadorismo [...]. Por isso a importância de dialogar com assistentes sociais que estão no exercício profissional [...]. Onde você está trabalhando hoje?

Hoje sou professor pesquisador convidado pela ULBRA [Universidade Luterana do Brasil]. Eles têm uma pesquisa, um grupo trabalhando com professores de diferentes áreas, que me interessa bastante, sobre a educação em pedagogia social. Eles sabem que a minha formação, meu doutoramento, foi nessa área na Espanha, em Santiago de Compostela. Me convidaram porque eu já tinha estado na ULBRA trabalhando, uma época como coordenador de curso e depois eu saí de lá porque você tem que fazer algumas opções na vida. Eu já estava na Universidade de Caxias do Sul desde setenta de seis [1976], onde fiquei trinta e três anos e fui levado para começar o curso de Serviço Social na UCS. [...] Mas a gente não nasce coordenador nem nasce chefe. Você fica um período e, na UCS era assim, por eleição, então você era eleito, era aceito pelo Departamento, pelo Centro, pela Reitoria, os alunos, todo mundo participava. Eu fui eleito, fiquei um bom periodo, pelo menos dois períodos de quatro anos, depois eu vi que tinha que continuar na linha de frente trabalhando. Quer dizer, eu não deixava de dar aula, mas, sabe como é, coordenação é um negócio administrativo, que te exige muita coisa. Ai eu voltei para a sala de aula, mas, não estava todo dia lá, eu ia e voltava, são duas horas de ônibus. Eu ia e voltava e, às vezes, ia numa sexta-feira, ficava o sábado, ia na segunda-feira e ficava na terça. Porque eu também sou funcionário público aposentado, sou técnico científico do estado, fiz concurso e fiquei no estado trinta e cinco anos. Então, em paralelo, eu tava [sic] trabalhando no estado como técnico, ao mesmo tempo estava como assistente social e eu entrei dentro da Universidade. Antes de entrar na Universidade de Caxias do Sul eu estive aqui na PUCRS IPontificia Universidade Católica do Rio Grande do Sul] no periodo de sessenta e seis, sessenta e sete [1966-1967], por aí. Depois que eu estive aqui fui para o interior trabalhar e quando voltei continuei no estado porque eu só estava desligado, eu podia estar nessa outra atividade que era de uma empresa do próprio estado como técnico. E quando eu voltei eu disse: "ah, vamos voltar pra minha área mesmo"! Porque não haveria interesse em ficar naquele trabalho. Era um negócio bastante complexo, obras. Começou a surgir as Febem [Fundações Estaduais para o Bem-Estar do Menor], FUNABEM [Fundação do Bem-Estar do Menor], e como eu era do estado, fui para lá. 


\section{Como assistente social?}

Sempre como assistente social. E na Febem eu fiquei trabalhando principalmente na área de planejamento. A minha esposa é assistente social também, mas ela ficava na execução e eu no planejamento. Ai eu aprendi uma coisa que eu já tinha aprendido com outros profissionais, a trabalhar em equipe multiprofissional com urbanistas, sociólogos, psicólogos, pedagogos, médicos. Enfim, para mim sempre foi uma coisa muito rica você trabalhar dessa forma e, evidentemente, você construir uma linguagem comum. Eu fiquei na Febem um bom tempo e tive a oportunidade de ir pra UCS. Nesse espaço de tempo também estive, como disse, na ULBRA. Fiquei nove anos na ULBRA trabalhando. Teve outras coisas que eu fiz ao mesmo tempo, dois periodos que eu fui presidente do Conselho Regional. A região era Paraná, Santa Catarina e Rio Grande do Sul.

\section{Da regional?}

Era regional, hoje é regional só o estado. Naquela época pegava três estados juntos, aí você tinha que andar viajando, caminhando, andando, conversando. E numa época meio pesada, porque nesse periodo a famosa redentora. Volta e meia nós estávamos em reunião, tinha um grande amigo do Bula, um grande colega com quem muito tempo estive trabalhando junto, 0 Tranquilo Gazola, que estava na secretaria do Conselho. Numa reunião à noite ele disse: "tem um telefonema pra você", eu peguei o telefone e era de Santa Catarina. Tinham preso nossa colega pelos militares, "o que é que nós vamos fazer?" Pensei, "vou ter que conversar com a assessoria juridica", e o advogado me disse assim: "me dá a passagem que amanhã de manhã eu tô lá, só saio de lá quando ela estiver em casa". E foi assim que aconteceu, fizemos em silêncio todo o trabalho e tiramos ela da jogada. Ela era militante, mas isso para mim pouco se me dava, era um colega, tinha que estar na sua atuação, se tinha outras coisas é problema de escolha de cada um, eu estava dirigindo a categoria. E foi nessas condições que eu concorri, a convite, à vice-presidência do
Conselho Federal. Fiquei no Conselho Federal como vice-presidente e depois como presidente nacional, então eu viajava o Brasil inteiro.

\section{Que interessante! Qual o periodo que isso aconteceu?}

Eu teria que dar uma olhada nas datas, porque têm épocas que na vida profissional você faz muitas coisas articuladas, nunca é uma coisa assim solta. Por exemplo, só pra você ter uma ideia, eu tive um presidente na Febem que tinha sido meu professor de história no colégio, e ele perguntava: "tu tá representando tua categoria na Funabem, né?" Eu respondia que sim e ele dizia: "toda vez que tu fores pra lá eu quero conversar contigo na ida e na volta". Raríssimo, ninguém dava bola pra isso. "De novo passeando?" Essa era a conversa que a gente ouvia até dos colegas. Mas a cada quinze dias eu estava no Rio IRio de Janeirol despachando no Conselho Federal, de lá e eu ia pra Funabem pra participar das reuniões e voltava. Saía de manhã cedinho no primeiro avião e voltava no último, dava um jeito, tinha que estar aqui de volta porque no dia seguinte o serviço continuava igual, essas coisas você se acostuma. Nesse contexto todo de curso de Serviço Social eu tive vários professores fantásticos: Lucia Castillo, que foi professora muitos anos em Portugal; aqui na PUCRS a Maria de Lurdes Medeiros; na Guatemala, fazendo trabalhos, Seno Cornely; professores com muita vivência, muita experiência de campo, muito estudiosos. Um belo dia, o Seno me disse "eu tô te propondo ser eleito, mas tu vais fazer a campanha, ser eleito para o Conselho Internacional de Bem-Estar Social". Era o famoso ICSW IInternational Council on Social Welfare] para região da América Latina, pega do México pra baixo. Ele disse: "tu só tens que ativar teu espanhol, o inglês e o francês". Bom, a gente dá um jeito, eu sabia isso, então eu me candidatei, fui eleito em oitenta e seis [1986], na Alemanha, em Berlim, e foi bem perigoso porque, no ano seguinte, o muro caiu. Eu fiquei administrando a região até noventa e oito, por aí, mas eu terminei a minha administração na China. 


\section{E como você se organizava para participar desses espaços?}

A gente viajava o mundo trabalhando. Entrava nos paises, trabalhava com os colegas ou com os representantes da organização internacional, que existe até hoje. É uma organização de assessoria à Comissão Econômica e Social das Nações Unidas, então a responsabilidade era grande e eu tinha que estar na Argentina, daqui a pouco no Chile, daqui a pouco na Guatemala. Eu não tinha salário, eu tinha apenas a passagem e a hospedagem, quer dizer, o valor relativo a uma hospedagem. No Brasil, até hoje, tem o Comitê Brasileiro, o CBCISS ICentro Brasileiro de Cooperação e Intercâmbio de Serviços Sociais], que realiza eventos internacionais. É fantástico você participar de uma coisa dessas, porque você tem uma visão de mundo não somente lendo, você tem a visão de mundo conversando com as pessoas, discutindo, analisando. E não só assistentes sociais, mas gente de todas as formações voltadas para a questão do social. Eu que já vivi muitas coisas de universidade, eu acho que ela ainda é pequena para isso, não consegue ser universidade, ela ainda é uma escola grande, que traz muita coisa, mas falta isso. Não é que todo mundo tenha que andar na rua, mas as pessoas têm uma visão de mundo um pouquinho diferente do livro. O livro é bom, a minha esposa e eu temos um apartamento de vinte e cinco metros quadrados que é só nossa biblioteca e eu herdei três bibliotecas particulares de profissionais. Mas além do que nós já temos, eu acho interessante você estar sempre discutindo, conversando, analisando, abrindo um pouco mais os teus horizontes. Eu fiz a caminhada aqui dentro, conheci todo o meu estado viajando, trabalhando com as pessoas, analisando as questões, em programas municipais, programas privados, tudo. Depois, a nivel nacional, circulei o Brasil inteiro conversando com os colegas nas sedes dos Conselhos da profissão. Depois a experiência internacional, que exigia da gente uma disponibilidade diferente. Muitas vezes, as chefias faziam cara amarrada: "de novo viajando a passeio?" Se você é esperto você tenta entender, ler um pouco antes de chegar sobre as estatísticas, as formas como são conduzidas as politicas sociais daquele país.

\section{Você passou também por experiências que avalia como negativas?}

Uma coisa que eu infelizmente peguei foi todo o periodo das ditaduras. Ditaduras militares na América Latina. Isso foi pesadissimo porque você entrava no aeroporto e te pediam tudo, isso é evidente. Eu vivi, experimentei. Mas muitas vezes era assim, estava conversando e discutindo com o colega lá da República Dominicana sobre as angústias que eles tinham, as perspectivas que eles tinham, e muitas vezes não eram só assistentes sociais, tinham sociólogos, médicos, advogados, era muito interessante porque você tinha diferentes vivências e experiências. Eu acho assim, que em termos de vida profissional eu não tenho queixa nenhuma, porque quando chegou a hora de terminar, trinta e cinco anos no estado, "tchau, cumpri minha tarefa". Aprendi a fazer tudo isso em conjunto e, muitas vezes, tendo que raciocinar em idiomas diferentes.

\section{E você parou de trabalhar nesse periodo?}

Eu entrei no estado em sessenta e seis [1966], por aí. Quando eu deixei, disse para mim: "não, chega, você tem que fazer outras coisas". Quando eu pensei que ia ficar mais ou menos calmo, o pessoal da ULBRA disse que precisava de mim. Então nós estamos montando, entre outras coisas na pesquisa, uma reflexão sobre universidade a partir da extensão. É lá na extensão que você entra em contato com a população, com programas. Aí é que se descobre coisas que são interessantes pra pesquisa, é lá que você vai ver coisas que devem ser revistas na sala de aula. Essa é nossa caminhada, nossa perspectiva.

\section{Você citou no início que trabalha com pro- fessores de diferentes áreas?}

Isso é uma coisa que eu aprendi com os professores, porque eram pessoas que estavam na 
linha de frente. Seno Cornely, por exemplo, uma das coisas que eu aprendi com ele foi a trabalhar com outros profissionais, que não assistentes sociais. Você tem que saber trabalhar com urbanista, por exemplo, para entender a questão do que é o mundo urbano. O que é que significa isso em termos de circulação? Por que o transporte? Então é importante você começar a vivenciar, por exemplo, com um arquiteto, como é que ele enxerga o que você não vê. Isso é uma coisa interessante, hoje nós estamos encaixotados, não é pela arquitetura e pela engenharia, é pela área imobiliária, os valores financeiros são altíssimos. Num mesmo local que caberia uma familia de até dez pessoas, tu tens trinta, quarenta, cinquenta familias, tudo amontoadinho. Sem saber o que é que é condomínio, só sabe o domínio. São coisas assim que você começa a aprender com gente que não é da tua área. No serviço social eu aprendi muita coisa e, inclusive, vivi algumas coisas que até hoje são passadas como verdade. Por exemplo, eu recebi, há alguns anos, um vídeo do Congresso da Virada. Eu estava lá e não foi isso, porque eu estava trabalhando no Congresso e a tal "virada" não aconteceu. Simplesmente mudaram a mesa de encerramento, entraram, uma colega nossa entrou praticamente com o Lula nos braços, fizeram um comício e isso foi dado como Congresso da Virada. A colega era a Luiza Erudina, que depois foi até prefeita de São Paulo. Gente, eu não tenho nada contra o partido, aliás, contra nenhum partido, mas o problema básico é este, eu acho que a profissão já é política, a nossa profissão já é política. Em segundo lugar, se você transformar em partido político, nós temos um problema sério.

\section{Importante essa sua experiência sobre o Congresso da Virada.}

Nós temos um problema sério no Brasil. Eu, por exemplo, sou filho de duas ditaduras. Quando nasci, em novecentos e quarenta [1940] nós estávamos na ditadura Vargas, era uma ditadura civil. Quando a gente pensou que ia respirar um pouco, aquela efervescência de sessenta e três [1963], em sessenta e quatro [1964] com as reformas, com o governo João Goulart e essa coisa toda, botaram a mão em cima e acabaram com tudo. Da noite pro dia. Um longo período de ditadura de novo. Como é que ficam as gerações nisso? Porque a gente não tinha visão política anterior, nós tínhamos uma visão totalmente encaixotada. Na ditadura Vargas ele criou o partido trabalhista [PTB] e criou o partido social democrático [PSB], porque tem que ter situação e oposição, entre aspas. A ditadura militar fez a mesma coisa, o que nós temos hoje é o resultado disso tudo. Então, eu não consigo ver programas políticos dentro dos partidos políticos, eu só vejo um conglomerado de insatisfações. Isso é um problema dos longos periodos na Argentina, no Uruguai, no Chile, $n$ Paraguai, na Bolivia. E se você for seguindo todos eles, periodos muito longos de ditadura, isso acabou com as pessoas, é um absurdo. Porque não se senta para conversar e ver: qual é a nossa proposta? O que é que nós estamos querendo levar avante? Isto é do partido? Como é que as profissões entram dentro disso? Porque a justaposição das profissões não se dá por um estalar de dedos, se dá por um processo educativo. O que é que eu aprendo contigo e o que tu aprendes comigo? O que é que nós estamos querendo com esta educação? Nós não temos hoje nenhum programa válido de educação fundamental. Tem muita coisa, mas não temos um programa válido para a pré-escola, mas temos programas muito interessantes para as prisões. Qual é a valorização de um professor? "Ah, mas ele é engajado politicamente". Ele está engajado com o povo dele? Ele sabe se comunicar com o povo dele?

\section{E como você se tornou professor do curso de Serviço Social?}

Eu terminei o curso em sessenta e seis, sessenta e sete [1966-1967]. E até tu podes perguntar "como é que esse cara foi cair no Serviço Social?". Bom, eu fiz um curso num dos colégios, hoje um dos mais caros de Porto Alegre, o Anchieta, com a tradição jesuítica fantástica desde as missões. Eu tive professores como Balduíno Rambo, o maior 
botânico da América Latina, e Mathias Schmidt, que era químico, doutor em química na Suiça. Mas o colégio te preparava pra três coisas: engenharia, medicina e direito. Eu pensava: "engenharia não é meu campo, mas medicina é interessante". Terminei o colégio em sessenta [1960], e na noite da formatura, terminando o científico, no dia seguinte eu estava entrando no exército. Eu sou oficial da reserva, não remunerado, passei dois anos no exército. E interessante o curso que eu fiz, intendência. É considerada a rainha da logística, prepara tudo o que tu precisares, desde material bélico, combustivel, alimentação, tudo é feito por esse setor. Fiz dois anos e nesse espaço de tempo um professor meu, que tinha feito um curso de orientação educacional em Lovaina, na Bélgica, perguntou o que eu queria fazer e eu respondi: "eu tô me preparando pra fazer vestibular em medicina". Ele fez assim: "eu acho que não é bem isso, mas tudo bem. Eu tenho uma proposta para ti. Nós temos aqui no colégio cinquenta alunos que vão para a rua, estão perdidos, mas eu acho que nós temos um trabalho para fazer com eles e eu me proponho, mas preciso de ti". Então ele me orientou, todas as tardes eu ia no colégio, ficava com a turma toda e tinha que ver como é que eles estavam se organizando ou não estavam se organizando. No final do ano ele disse que oitenta por cento foram aprovados. Eu fiquei dois anos fazendo essa experiência, e aí no final ele perguntou se eu queria fazer um teste vocacional. Fiz um mês de testes, foram entrevistas e conversas, e no final ele disse assim: "Sabe o que é que deu? Serviço Social! Mas não te preocupa, vai na PUCRS, marca uma entrevista com um assistente social e vê o que é que tu achas". Eu marquei a entrevista e a assistente social que me atendeu foi Nara da Costa Rodrigues. Fiz o curso, terminei em sessenta e seis [1966], fui o primeiro da turma.

\section{Parabéns!}

Vou te dizer assim, acho que ainda estou aprendendo, porque tem muita coisa e não me arrependo um minuto. Foi exatamente numa caminhada, numa viagem de trabalho para o interior do estado aqui, que o Seno me disse assim: "escuta, tu vais fazer um trabalho em Rio Grande, mas eu vou botar um cara junto contigo. Tu és muito novo ainda, está recém no segundo ano do curso. Tu vais à Rio Grande, eles estão pedindo um seminário de desenvolvimento de comunidade". Era uma época que começou a surgir muito isso aqui no Sul e ele disse para eu passar em Pelotas, que tem curso de Serviço Social também. Ai passamos e só tinham três alunas [...]. Naquela época de sessenta e três, sessenta e quatro [1963-1964], se estudava Lebret [Louis-Joseph Lebret, economista e religioso católico dominicano francês], os manifestos dele e os estudos que ele fazia, era uma época em que você estava começando a ver o Serviço Social de uma maneira diferente, que não era aquela visão... Eu não gosto muito que muitas pessoas dizem assim "aquela visão psicossocial", nós não podemos abandonar as origens! Se aprendeu muita coisa com o Serviço Social americano, se aprendeu muita coisa com o Serviço Social europeu. Nós não nascemos sabendo das coisas, então a gente aprendeu [...]. Então você vai evoluindo, claro que com esses periodos de ditadura fecham, né? Então você também perde muita coisa. Como eu viajava eu tinha a possibilidade de ir catando e redescobrindo toda a caminhada do Paulo Freire lá no Chile e outras coisas, muita gente que teve que abandonar o país, então você começa a ter uma outra visão de serviço social. Não é que vai ser a visão desenvolvimentista. Acho que nós estávamos ali saindo de uma visão psicossocial para uma visão macro e estávamos agarrando onde dava para fazer as coisas, com os programas que existiam.

\section{Era o conhecimento que se tinha acesso na época?}

Exatamente. Hoje você tem que ter um pouco mais de cuidado, porque tem coisa demais que não serve para nada. Casualmente eu estou lendo, nesse momento, um livro que se chama A Inutilidade do Útil, é de um italiano. 


\section{Como é o nome dele?}

Ele foi traduzido pelo Luis Carlos Bombassaro da Universidade de Caxias do Sul. Ele saiu agora, tá até na Feira do Livro [A Utilidade do Inútil, Nuccio Ordine]. Mas é uma paulada, porque você tem que estar muito atento a não cair na conversa, uma frasezinha que ele marcou: "a ditadura eficaz, a mídia diz e você faz". Então nós estamos vivendo também a época da pós-verdade, tudo isto você tem que estar olhando em cada época. Eu vivi essas épocas todas assim, com possibilidade de conversar com gente de tudo o quanto era coisa, informação e programas diferentes. E quando começou aquela história do PT [Partido dos Trabalhadores], é aquela coisa, quando a criança começa a engatinhar ela meio que cai, não fica. A gente está fazendo a mesma coisa, nós estamos meio que nos enganando um pouquinho com tudo isso, porque não existe o líder carismático, isso já terminou, no mundo de hoje isso é bobagem. Tem coisas que você tem que ver, as pessoas, as lideranças rodeadas não de puxa-sacos, mas de gente competente. Não da forma como, por exemplo, o nosso prefeito faz, porque infelizmente eu trabalhei com o pai dele. Ele faz aquele grupo de talentos, mas não ficou ninguém, você pode queimar gente boa. [...] Eu acho que tem umas coisas doentias que são sobras dos periodos ditatoriais e custam muito a sair, custam muito a sair. A gente tem que estar muito atento a não pegar, tem coisa que tem que ser analisada ali, quanto mais for um grupo heterogêneo, for um grupo transdisciplinar ou interdisciplinar, ou que nome você queira colocar. Eu, por exemplo, lá no grupo lá está se estudando muito a questão da transversalidade da acessibilidade, que quando se fala em acessibilidade você só fica pensando na rampinha da esquina.

\section{É verdade, é muito mais que isso.}

Acessibilidade econômica, social, política, jurídica, de tudo quanto você quiser. Mas como é que se junta? Isso só se faz estudando junto, estudando junto e propondo junto, e experi- mentando junto. A ULBRA vai fazer no próximo ano um evento internacional sobre a questão da acessibilidade. Então já estou recebendo material novissimo e você fica assim: "Minha nossa! Como essa gente tá na frente!". Como é que tu consegues saber coisas que são do interesse do ser humano? Como é que você consegue fazer isso? Muitas vezes, eu fico vendo as entrevistas que fazem com as pessoas, por exemplo, ontem eu vi: "mas a senhora conseguiu retirar o seu décimo terceiro?" "Não, não deu nada, eu perdi tempo aqui e não consegui coisa nenhuma, esse governador...". Quer dizer, as pessoas seguram na casquinha. Nós estamos fazendo as pessoas perderem tempo, e o pior, e que mais me magoa é que são pessoas de idade, ou seja, estão mantendo essas pessoas longe de tudo. E o novo hoje é uma coisa fantástica, o novo ele não sabe mais conversar olhando nos olhos, ele só sabe olhar para esse aparelhinho [aparelho celular] e eu sinceramente, eu ainda sou do tempo que quer enxergar o outro. Isso aqui é muito bom, é um espetáculo, mas... É interessante a gente olhar essas coisas do dia a dia e ver como nós, na nossa profissão, estamos o tempo todo envolvidos por isso. Nas diferentes épocas que você passa - e a gente acaba sendo um privilegiado porque passou por várias épocas e não passou de avião, aprendeu a conviver com as pessoas e essa convivência você não perde - tu tens que estar muito atento àquela convivência com a pessoa que tu nunca viste e que tem a maior simplicidade do mundo até no falar, te diz coisas fantásticas, e percebendo que tipo de mundo está atrás de tudo isso. A nossa profissão é interessantíssima por causa disso, ela te permite, primeiro, saber ouvir, tem gente, hoje, que não está ouvindo, está só escutando. Também ver, tem gente que só está olhando. E são três coisas: Saber ouvir, saber ver e saber propor. Porque tem gente que simplesmente dá palpite, né? Então, isso tudo te demanda uma questão ética, evidentemente. $\mathrm{E}$ com a minha esposa eu aprendi muito porque ela nunca fez esse trabalho, digamos, macro, eu não considero macro, eu considero um trabalho. Ela sempre fez o trabalho de miudinho, ou seja, 
ia nas vilas, ia pra [sic] isso: conversava com as pessoas. Muitas vezes em domingo ela dizia: "te ajeita aí porque eu tô levando as crianças para o presídio em Charqueadas pra reverem os pais". Mas isso é trabalho de assistente social? Gente, é o direito da criança! Vai ficar discutindo se o pai é isso, se a mãe é aquilo, isso é outra questão. É o direito de verem os pais. Tu passas a permanentemente estar sendo exigido por um outro ser humano que tem os mesmos interesses, as mesmas coisas, mas que provavelmente tu não sabes se sabe tudo, mas ele também não. Ele sabe alguma coisa. Com o que nós sabemos, o que nós vivemos, podemos fazer um trabalho bom. Agora, eu achando que sei tudo, esquece.

Jorge, vou passar a fazer perguntas mais gerais sobre a tua atuação profissional na história recente, durante o período dos governos Dilma, Lula, articulando também questões sobre o governo FHC [Fernando Henrique Cardoso]. [...]. Você acredita que as políticas e programas implementados nos governos Lula e Dilma interferiram diretamente na tua atuação profissional?

Interfere sim. Eu sou profissional, mas sou brasileiro, cidadão que vota, é evidente que essas coisas mexem. Todo programa governamental mexe com a tua vida, todo ele. A conversa neoliberal é assim: "não te preocupes porque aquele que tem que pagar mais vai pagar mais e o que tem que pagar menos não vai pagar nada!". Isso é populismo, isso não existe, é conversa pra enganar torcida. A gente fala na Dilma, a Dilma eu conheci nos primeiros momentos dela, como secretária de Energia e Comunicação do estado e sabia perfeitamente que ela tinha passado por tortura.

\section{$\mathrm{Na}$ ditadura militar.}

Na ditadura. Então, ela seguiu o, vamos dizer assim: "vamos continuar a ideia de Lula, vamos continuar os programas dele". Só que tem uma coisa muito séria que, como eu já fui funcionário público e vivenciei tudo isto, sei que se tu és a pessoa da minha confiança, que eu posso contar contigo, nós somos do mesmo partido, tu és a pessoa nesse momento prontinha pra assumir a chefia, tu podes chegar e negar. Mas a turma que está em roda faz pressão e diz que é a oportunidade, tem que ser feito, é agora, nós temos que conseguir isso. E ela entrou. Entrou, como se diz na gíria, de gaiata, ela entrou e não conseguiu mais sair, ela foi entrada na história toda, tanto é que todo mundo caiu fora. E ficaram conversando coisas que, pra [sic] uma mulher que passou por uma situação como ela passou, um pingo de respeito nesse país devia ter havido. Eu não tô nem discutindo a questão se deu pedalada, se não deu pedalada, se roubou ou não... Isso é outra questão. O próprio Lula foi líder sindical saindo de uma ditadura, nesse ponto foi fantástico, mas ai vem um outro problema: ele caiu dentro do ninho. E o ninho é terrivel, porque o ninho político brasileiro te amassa, ele te consome. Ou tu entras ou tu saltas fora, não tem jeito. Porque não tem programa, tem interesses. E os interesses empresariais, os interesses comerciais, os interesses internacionais, é um negócio que no dia a dia como presidente, tu não vais conseguir fazer nem a metade. "Ah, mas ele ganhou um apartamento, porque a dona Marisa..." Estão brincando com coisa séria, pra mim isso é bobagem. O mais importante é: Como é que ficaram as nossas relações internacionais, economicamente falando, a partir das ditaduras? Veio o FHC, mas enquanto ele escrevia como sociólogo é uma coisa, depois que ele sentou na cadeira, ele foi sentado. Eu não estou tirando a responsabilidade deles, mas ele, o Lula, a Dilma e essa turma que está aí, eles foram sentados, eles não sentaram na cadeira, eles não sabiam, eles não tinham a noção de tudo o que estava ali. [...] Isso é o Brasil inteiro e a América Latina igual, só que com umas nuances espanholas que são terriveis que eu sei também.

Nessa perspectiva, você delimita alguma diferença entre o governo FHC e os governos petistas de Lula e Dilma?

O problema básico é o seguinte, o FHC tem um programa, ele foi assumido pelo chamado PSDB, que é um programa neoliberal. Porque o neolibe- 
ralismo está no mundo inteiro fazendo o que bem entende, e com esse sistema de multinacionais, até as nossas empreiteiras viraram multinacionais [...]. Eles prepararam muitas coisas porque eles estavam com ligações com os americanos, com os ingleses, com os franceses, japoneses, só não podia ter com os comunistas. [...]. Quando veio o FHC como neoliberal, entrou na roda neoliberal do mundo inteiro. E o que é que aconteceu com a entrada do Lula? O Lula vinha de uma outra estirpe, os metalúrgicos no Brasil sempre foram ponta, nunca foram retaguarda, não, eu mesmo estive fazendo estágio como aluno do Serviço Social no Sindicato dos Metalúrgicos em Porto Alegre e convivi com a turma, eu sabia como é que aquilo andava. Na época, o presidente se reunia com a turma toda, toda a diretoria, eles são muito mais ágeis, politicamente falando, do que os demais sindicatos. Quando entrava uma questão de greve eles estavam na frente. Então, o Lula tinha uma história, ele não veio do nada, era metalúrgico, veio vindo e de dentro de fábricas. Os controles dentro das fábricas do periodo da ditadura têm resquicios até hoje, volta e meia se descobre um cara que era olheiro. Então era uma guerra essa história toda. Quando ele veio pra fora, quando incensaram ele pra ser presidente, foi um salto mortal, né? Ele não foi prefeito nem governador. Não teve ninguém que dissesse: "Escuta, cuidado com isso, tu tá entrando numa fria". Todo mundo tava: "Vamos lá, é agora a hora do partido, vamos lá!". Fizeram programas sociais? Sim, tem muitos programas sociais, que ainda estão meio capengas andando por aí [...]. Eu convivi com chefes, com secretários de Estado, e eles só conviviam com gente deles. Esse é o perigo, porque tu só ficas ouvindo o que tu queres ouvir, de repente o ouvido fica surdo, só ouve o que interessa, ou seja, tu não te acostuma mais a ouvir o contrário. E isto é um problema. Não é culpa do Lula, não, mas ele é culpado enquanto ele não percebeu que o salto era mortal, e os que estavam com ele fizeram a mesma coisa. Segundo lugar, os grandes conglomerados neoliberais, internacionais, chineses, tu não tens ideia do poder que esses caras têm.
Então, saímos de uma visão neoliberal lá com o FHC pra uma visão neossocial com o Lula. Pra continuar ele achou: "vamos botar a Dilma". Isso é o perigo, tu vais continuando, não se faz isso. Teve o teu tempo, terminou. Foi o que eu fiz, o meu tempo terminou, da profissão, dirigindo o Conselho, terminou, tchau, já fiz, o que não fiz também não é agora que eu vou fazer. A nivel federal foi a mesma coisa, a nivel internacional foi a mesma coisa. Tu tens que saber o teu momento e o teu tempo e com quem tu estás.

\section{E em tuas experiências de trabalho, quais mudanças tu identificas entre esse período FHC e Lula-Dilma?}

Como nós vínhamos do periodo de ditadura em que os programas vinham engessados de cima para baixo... O que aconteceu com eles foi que aqueles programas foram anatematizados, isso é um perigo. Tem coisas boas que foram postas fora, agora é o novo mundo, a nova época, é um Brasil novo. Eu acho que isso é bom pra propaganda. Na efetividade do dia a dia, por exemplo, uma coisa bem simples: "minha casa é minha gente". O pessoal continua sem ter onde morar, continua sem comer. Eles continuam sem morada, olha a quantidade de gente que continua sem nada, sem perspectiva. Eles não têm perspectiva porque foram acabando os programas todos, eles tinham possibilidade. Tu vês o Temer [Michel Temer]: "aumentamos em tantos por cento os empregos". Ai tu viras a página do jornal, o número de desempregados que eles não falam. E a mídia é viva, não fala entre o empregado permanente e o empregado eventual.

\section{Você avalia que esses programas foram aca-} bando com a ascensão do Temer, é isso?

Sim, é evidente, agora está mais nitido ainda. "Não, porque tem que fazer a reforma da Previdência ...". Tu já viste que só as palavras contrárias recebem uma coisinha desse tamanho na midia e as outras o destaque? Porque tem interesses atrás disso, interesses caríssimos. Tem gente que 
está sobrevivendo - o jornal, a emissora, televisão, esses meios todos de comunicação - com isso. Então a ética da coisa se foi para o espaço. Porque essa programação está anacrônica, primeiro porque foi abandonada, e em segundo lugar, ela não sofreu avaliação nem reavaliação. Não houve ninguém que questionasse "vamos dar uma olhada agora pra ver se há uma efetividade nos programas habitacionais. Eu vivi desde o início das Cohab [Companhias de Habitação], depois veio o Banco Nacional da Habitação. Quanta casa, quanto apartamento de luxo foi construido com isso? E quanta casa se deixou de fazer? Tu não mexes sem mais nem menos nos programas, porque se tem muito interesse por trás disso. Isso vale para o médico, se ele tentar fazer qualquer coisa no hospital ele recebe um aviso; o advogado, se começar a botar as alças de fora, a turma do júri já está ali. Eu saía caminhando no meio dos alunos e dos professores e chegava o Pró-reitor e dizia assim: "cuida mais dos teus vermelhinhos". Qual é a diferença? "Ah, mas você é pessimista, mas você não está vendo nada de novo". Eu tô [sic] assim, pensando em como estar se preparando pra quando essa coisa desmoronar. Você tem que ter proposta, tem que ter alguma coisa, mas não pura e simplesmente "agora vai mudar o mundo". Não vai mudar, eu tenho que olhar o mundo todo como está. [...] Você tem que ver por exemplo a presença dos Jesuitas...

\section{Na América Latina.}

É, fizeram as reduções, e uma outra república que os impérios fecharam. Eu não tô dizendo que aquilo era uma maravilha, eu só tô dizendo que você vive num mundo onde passam as épocas e, se você não tiver atenção pra estas coisas, então o teu dia a dia passa a ser uma brincadeira de salão. "Eu tô fazendo meu trabalho, atendi tantas pessoas hoje, vieram tantas pessoas no meu consultório, no meu programa, atendi tantas crianças". E daí? O que é que isso mudou? "Ah não, mas vamos resolver indo para o partido, vamos pra o partidão ou pra o partido PCdoB, PSOL, PLUA". Não importa o nome, acontece que não tem proposta nenhuma, só tem conversa, só tem coisas estomacais, está faltando o resto. E isso é um distanciamento que eu vejo entre as universidades, onde estão os núcleos de pensamento, de avanço [...] Mandam embora cento e trinta professores [...] Quanto tempo levou pra fazer essa gente? Por que é que não são excelências? De pensamento, de ação e de proposta. Não, é sala de aula. A pesquisa é importante, senão tu te tornas uma torre de marfim. O que é que é a extensão? "É uma coisinha de assistência social que se faz ai pra esses coitadinhos terem o que fazer" Essa é a visão completamente fora da casinha, não tô vendo o mundo todo. E isso não é comentado e discutido. [...] Imagina dar aula para a graduação "Olha, eu sou pós-doutor!". Nós nos metemos numa torre de marfim que tá sem base. As universidades, no caso brasileiro principalmente, todas são novíssimas, então tem muita coisa boa e tem muita bobagem, só que uma não conversa com a outra. "Tu é da PUCRS?" "Eu sou da UFRGS.". Que coisa idiota, um povo como o nosso é deixado fora e você não discute essas coisas entre as universidades. Você veio de longe pra estudar aqui, olha só, veio do outro lado do país. E você veio pra procurar alguma coisa que aprofundasse as tuas questões, as tuas buscas como pesquisadora, como profissional de linha. Sai com o título. Porque se tu não tiveres o título de doutor tu vai ganhar cinco pila, agora se tu ganhas o título de doutor tu vai ganhar um pila a mais. Gente, nós estamos brincando com isso, eu fico muito danado porque eu acho que é vigarice mesmo. Tu ficas te matando, tu ficas tentando, tu fazes o máximo, o que é que tu consegues com isso? É conversa fiada, falta essa criticidade, olha o tamanho da universidade.

\section{É um mundo. Era pra ser um mundo.}

Eu quando comecei a estudar na PUCRS era lá no centro, onde é o Colégio Rosário. Ali que era a PUCRS, tinha cinco cursos e mais nada. Um detalhe, o chanceler foi o cara que me batizou quando era o pároco de uma igreja aqui em Porto Alegre, onde eu nasci, no bairro onde eu nasci. 
Então ele disse assim uma vez, conversando lá em casa com a minha mãe, minha mãe que era evangélica luterana! Ele dizia assim: "O que é que a senhora, que é professora, tem curso e tudo, o que é que a senhora acha de nós termos uma universidade católica?". Ela disse que era interessante, mas a ideia seria: o que é que os luteranos têm a dar para com os católicos ou vice-versa? Só agora, depois de quinhentos anos, está havendo uma aproximação entre os católicos e os luteranos. Isso eu disse num encontro que houve lá na ULBRA, eu disse "Vocês estão aqui, vocês alunos, estão dentro de uma universidade que tem como patrono um revolucionário, um cara que abriu a boca e pagou o pato com isso, mas abriu a boca. Isso é o diferencial de vocês". Qual é a mensagem da universidade na ULBRA? $A$ verdade vos libertará. Só que a verdade não é a minha. A PUCRS também tem o seu lema. Quando a gente começou eram só cinco cursos, não tinha mais nada, isso aqui era um matagal.

\section{Casas prédios, aqui não existiam?}

Não tinha nada, nada, nada, nada. Então, o que é que isso significa hoje em termos de inteligência? Deve ser a torre de marfim. Porque eu me coloco dentro disso e é a mesma coisa que diziam lá na universidade de Caxias do Sul: "isso aqui é uma universidade regional e comunitária". Eu digo que regional ela até pode ser, mas comunitária umas favas, porque os italianos são muito fechados, se tu não és italiano, tu ès estrangeiro.

\section{Entendo.}

Então o tema que tu estás mexendo é uma coisa que deveria estar num outro patamar e que está ainda sendo vivenciado na Idade Média, com todo o respeito à Idade Média. Claro, porque o que é que eu transo com outras universidades aqui de Porto Alegre? Com a universidade, digamos, de Cochabamba na Bolívia? O que é que eu tenho de articulação com a universidade? No Brasil não tem nada. É por isso que se volta de novo a um Fernando Henrique Cardoso, homens que se formaram dentro de torres de marfim.

\section{E que quando vai pra realidade...}

A coisa muda. E o outro que não estava dentro da torre de marfim foi colocado numa coisa construida. É interessante que nós não temos uma proposta de universidade interna, é um colégião. Com todo o devido respeito, mas é um colégião. Todas elas estão assim. Segundo lugar, não existe uma transa entre elas. Terceiro, o pessoal que se forma e fica emparedado. Então, eu não sou pessimista, eu sou realista. Em bom português: tem saída. Mas será que nós vamos sair sozinhos? Não, não acredito. E o interessante é que as pessoas têm medo do grupo, têm medo da equipe, não da "euquipe". Porque a equipe incomoda, a equipe propõe, a equipe faz, a equipe desenvolve, a equipe avalia. Isso é planejamento, isso é visão de ponta. O que é que, por exemplo, as universidades estão fazendo em termos de mudança política, não pra dois mil e dezoito, pra dois mil e vinte, dois mil e... Não tem nada sendo feito. E, se tem, está fechado à sete chaves.

\section{E o que é que tu achas do impeachment da Dilma? Pontualmente, o que é que você pensa que isso significou?}

Para mim foi golpe. Porque, desculpe, pedaladas fiscais, ou seja lá o que for o nome que colocaram. Qual foi o aspecto central que fez com que ela tivesse que ser retirada? Esse motivo que é colocado pela mídia não é motivo. Porque está sendo feito igual só que com outro nome. Isso banalizou a coisa, porque ela poderia muito bem ter ficado, ter respondido a um processo realmente politico ou responder um processo jurídico depois do mandato dela, sem problema nenhum. Não precisa fazer isso, isso é o velho sistema latino-americano. As elites vão e mandam e desmandam o tempo todo. Casa grande e senzala. Teve uma coisa também que foi esquecida: mulher. Foi esquecido.

\section{Só isso já é um fator.}

"Desde quando nós vamos ser dirigidos por uma mulher?" Porque sempre foi com homens. 
Olha o que fizeram com a governadora que teve aqui também, colocaram ela na linha de frente, isso é sem-vergonhice. E era "só aceita". Ou muda todo mundo ou não muda, porque a turminha que está em volta...

\section{Vai como bode expiatório?}

É bode expiatório. Porque no Brasil, desculpe. Nós temos que entender um pouquinho de política, de ciência política, e aí houve safadeza. Não havia nenhum motivo sério no processo constitucional pra tirar ela. É o golpe branco. O golpe armado bota as tropas na rua e acaba com a festa, esse é um golpe branco.

\section{E pelo que você tem percebido, no seu coti-} diano, dos colegas de trabalho, que mudanças você observa?

As mudanças estão sendo, todas elas, do ponto de vista econômico e financeiro. Na hora em que tu colocas a provisoriedade na Justiça - não tô te dizendo que a Justiça do Trabalho é imutável, tudo precisa de aperfeiçoamento, mas não de mudanças safadas. O que nós estamos vivendo é mudança safada, novamente do periodo colonial. Se tu não tens essa visão da precarização do trabalho, do emprego, das leis trabalhistas, pensa "Eu não sou atingido por enquanto, não sou aposentado", "ah, não tenho nada a ver com isso". Mas estão havendo melhorias, eles dizem: "nós estamos até trazendo os Médicos Sem Fronteiras, nós estamos fazendo uns postos de saúde". Eu ouço do pessoal mais simples do povo, muitas vezes, que chegava lá no posto, a médica olhava e dizia "E daí, qual é o problema?". "Agora tem uma lá que fala meio gozado, a gente não entende bem, mas ela fica com a gente, fica conversando. Só pode ser dos Médicos Sem Fronteiras. É interessante isso, tu trazes esse outro pra preservar aquele, então este põe a cara porque está acostumado, ele quer, está buscando [...]. Hoje toda a linha de frente, até na porta, são estagiários. Precarização do serviço público. Isto é fruto de uma época, nós estamos precarizando. "O pessoal do serviço público tá ganhando demais, é uma loucura o que estão ganhando". Espera um pouquinho, você está falando de alguns desembargadores, dos deputados, dos vereadores. Olha o caso de um vereador de Porto Alegre, o camarada é o chefe de um ramo de imobiliárias, pediu uma funcionária da prefeitura para sua assessoria. E sabe onde é que ele colocou ela? Cuidando do negócio dele. Chegamos ao ponto máximo de mentir que está tudo bem, tá tudo funcionando perfeitamente bem. Só que se tu olhares, vai num posto de saúde no bairro, qualquer bairro, vai ver como é que a coisa funciona. Senta lá um pouquinho e assiste a coisa. Isso eu faço. Não preciso avaliar. Mas se eu faço é porque eu não quero ficar só com a conversa escrita, eu quero ver como é que a coisa é.[...] tem mil maneiras de ser subversivo, é só usar a cuca.

\section{E nesse contexto de queda do governo Dilma, tu consegues enxergar manifestações de um avanço do movimento conservador?}

Os diferentes movimentos estão muito mais vivos do que nunca. Primeiro, eles nunca morreram, tanto é que nós tivemos as ditaduras conservadoras. Isso faz parte da nossa história, não é uma condenação, é uma constatação. Se tu olhares o Brasil Colônia, vais perceber que o movimento conservador sempre existiu, ele foi importado e trazido pra cá, porque isso aqui não deixava de ser uma senzala grande do contexto europeu. [...] Eles têm mil maneiras inteligentes de fazer as coisas porque eles estão anos nisso. Eles não apareceram agora, têm anos fazendo isso. O Brasil Colônia, o Brasil Império, a República Velha, foi sempre assim. Se tu olhares a história do Rio Grande do Sul, nós tivemos presidentes aqui do estado que ficavam dez, quinze anos. Isso veio porque o nosso estado, aqui... Em primeiro lugar, não era nem pra ser brasileiro, era pra ficar no Uruguai. Aqui houve uma guerra que nunca foi explicada, até hoje não está explicado isso. Houve, contra o império. Se era para fazer uma república ou não, isso aí é outra questão. Acon- 
tece que foi, no fundo, sustentada pelo pessoal do dinheiro, não foi pelo povo, o povo foi posto na linha de frente para morrer. Tem essas coisas que você tem que saber ler a história. O Brasil como um todo é extremamente conservador.

\section{E o que tu compreendes por conservadorismo?}

Manter familia, tradição e propriedade. Manter, mesmo que a familia esteja caindo aos pedaços. É outra visão de familia que a da sociologia, tem muitas famílias diferentes, mas aquela visão que existia da familia que mandava, que o velho era o chefe, que a mulher era submissa. [...] A familia nuclear, a familia patriarcal, a familia tradicional, aqui ainda se endeusa um pouco isso, e no restante do Brasil [...] O conservadorismo nosso é em todos os aspectos. E chega ao ponto do ridículo.

E o que você pensa sobre os eventos políticos do Brasil recente? Enxerga elementos de conservadorismo?

Os eventos políticos estão muito invisiveis. Tem gente da oposição, mas não consegue porque as transas de dinheiro são muito fortes, porque tem gente que tem poder, eles têm poder. O nosso parlamento hoje está completamente viciado. A Justiça tá na ponta da faca, porque também tu vês as manifestações como de Gilberto Mendes, por exemplo, mas não dizem nem antes, nem porquê, nem como. Então, nós vivemos nesse momento uma visão assim: "vai mudar para o quê?" Não tem proposta. Olha o que a midia está fazendo: "Vai ser o Lula, vai ser o Bolsonaro, vai ser fulana, vai ser beltrana". Isso é plantar pra ver se cola. Não é real. Não existe isso, porque não existe programa. [...] Quando a coisa é feita muito "familiaresca", o que que acontece. Mas é assim que se dirige o país em tudo que é lugar. [...] Não sou puxa-saco, nunca fui. Eu aprendi com meu pai e com a minha mãe a ter dignidade, respeito e o trabalho sério. Dar o máximo. Porque você vai entrando, vai entrando e quando você vê, estão em volta de ti fazendo a isenção. Não dá, pra mim isso nunca existiu. É essa visão do "toma lá e dá cá". Cuidado, que isso existe em todas as organizações, mesmo no Brasil moderno, tecnológico que nós temos. Mais ainda, porque é feito e controlado. O conservadorismo brasileiro tá só modernizado, mas ele continua do mesmo jeito. Isso não é uma visão pessimista das coisas não [...].

Jorge, eu vou colocar agora alguns temas para que tu possas expressar um pouco o que tu pensas sobre cada um deles. Redução da maioridade penal, o que tu pensas sobre isso?

Como eu já vivi dentro da Febem e dentro da Funabem, que hoje é Fase [Fundação de Atendimento Socioeducativo do RS], tem também outros nomes... A questão sobre maioridade penal, a gente está entrando num terreno perigosíssimo, porque já é o terreno da terapia, o terreno final. Primeiro lugar, toda organização que trabalha com o ser humano tem que ter planejamento, não pode fazer coisas de improviso. Como eu não sou músico, não sou compositor, um Chopin, um Mozart, Beethoven, que faziam os famosos improvisos... Não se improvisa com o social.[...] A gente não faz o que foi sempre preconizado, vamos trabalhar preventivamente pra que esse pessoal, com antecedência, tenha todas as condições para ser gente, não "deter gente". Quando eu meto a mão na parte jurídica, a coisa tá feia, eu estou de novo sofrendo pressão de uma sociedade que quer pescoços [...].

\section{Cotas raciais.}

Isso é outra coisa que está dando uma "baita" polêmica....

Sim, todos os temas que eu vou citar são bem polêmicos!

Tá dando uma "baita" de uma polêmica por uma coisa bem simples. O aspecto é complexo pela história, pela antropologia. Vamos olhar a questão dos negros e depois de outros, ciganos, judeus... Quando você começa a fazer guetos é mau sinal, o gueto de Varsóvia e todos os guetos que a Europa colocou, a grande Europa que é o 
"máximo", não é? Foi ela que criou tudo isso, que escravizou os indigenas aqui, que escravizou os negros no contexto da África... tu conheces o Zimbabwe? A Rodésia? Porque a Rodésia pertenceu a um cidadão inglês que tinha o nome de Rodésia, é um país que tinha o nome dele! Hoje é Zimbabwe, porque é o nome típico da terra, mas o presidente tem que ser deposto e tá lá há quase 90 anos no poder. Então, quando você fala em cotas raciais: "Isso é pra garantir o espaço dessas pessoas!" É porque os espaços anteriores foram negados.

\section{Tu achas que se trata de uma questão histórica?}

É uma questão histórica, cultural, antropológica, política. Porque nós, os brancos, nos acostumamos a segregar os outros e achar os outros inferiores. O judeu é um pouco diferente a situação, é uma outra questão, mas as cotas raciais de mulatos, negros... Quando a gente começa a fazer isso, nós estamos na beira do precipício. Primeiro lugar, todos tinham que ter direito a estar na escola para poder chegar a alguma coisa, não é obrigado que todo mundo tenha que ir pra universidade não. Eu posso ter gente fantástica que está fora da universidade, fazendo maravilhas! Então... "Tá reservado o teu lugar!" Calma! Eu posso tornar ele um infeliz, porque não é isso que ele está buscando como ser humano, agora os que estão buscando e não têm condições porque não lhes é permitido, não ficam dentro daquela elite. Ai tem sem-vergonhice atrás. Então você faz umas concessões "deixa um pouquinho deles entrarem também... cotas raciais, que nome bonito, né?" Mas nós estamos "apatifando" o processo, porque ou esse país é realmente democrático ou só é "demo". Democrático não tem nada. Dá uma olhadinha pra ver como você deixou entrar, por exemplo, negros na universidade. Eles voltam a trabalhar com o seu povo? Não. Eles foram cooptados por nós. Então, eu tenho um pouco de medo dessas cotas raciais.

\section{Casamento de pessoas do mesmo sexo?}

Isso é uma coisa nova que está surgindo, porque essas questões foram sempre tratadas de uma maneira muito moralista, não de um ponto de vista sociológico, antropológico, psicológico. Isso é moderno, mais recente. [...] Eu não sei, sobre o ponto de vista de diferentes áreas científicas, o que representam estas pessoas. Isto é antigo na história da humanidade, sempre existiram. "Ah, mas casamento"! Gente, seja que moral for, se existe relação entre duas pessoas do mesmo sexo, e daí, qual é o problema? Nesse contexto de duas morais sexuais que pra mulher não é válido tudo e pro homem pode. "Por que ele pode e eu não posso?" "Ah, mas agora tá podendo". Se ela fizer determinadas coisas tu já olhas meio assim. Essas duas morais sexuais são terriveis, porque com elas vem de novo o conservadorismo, tem toda uma manobra em torno disso para manter essa posição. O importante é que os seres humanos sejam felizes, mas não conforme eu concebo.

\section{E sobre aborto, Jorge?}

[...] Então, a questão do aborto é aquela história, hoje mais do que nunca, porque novamente vem aquelas morais sexuais anteriores. Tu encontravas uma mulher e acabavam tendo um filho. Opa! A coisa foi um pouquinho longe demais, acho que a festança pode existir a vida inteira e deve existir, não tem problema nenhum. Mas esse ser humano não tem nada que ver com isso, se houve, há um descuido, a camisinha, a pílula... não vamos conversar com essas conversas fiadas, eu estou brincando com seres humanos. A criança nasceu, "Ah, então termina com ela". Isso é assassinato. Assim como você assassina o vivo deixando ele fora do atendimento, fazendo de conta que ele não existe. Essa criança que nasceu não pediu para estar ali. Nós estamos fazendo uma jogada com seres humanos, tudo se faz na prevenção e não na tentativa de arrumar, porque a tentativa de arrumação é caríssima. [...] Tu te preparares durante 9 meses... "Não... é ela quem faz". Espera um pouco, quem vai ter o filho são vocês dois, porque tu tens que te preparar como pai, a tua paternidade começou na concepção. Nós somos responsáveis, 
então eu tenho que me preparar para ser pai e não apenas homem. Eu sou profissional, sim, mas sou homem, sou ser humano, essas conjunções eu tenho que fazer o tempo todo. Então, o aborto, desta forma como é, é crime. Previne, hoje em dia tá fácil de prevenir. Há anos atrás, dez, vinte, trinta anos atrás, não tinha nada. Hoje tu tens. E aí que a gente vê como esse conhecimento que circula aqui dentro, não chega lá fora.

Para ti é crime em todos os casos? Mesmo aqueles já previstos em lei, como no caso de estupro, casos de risco de vida da mãe, má formação...

A questão do risco, por exemplo, não é uma coisa tão simples de ser assumida. "Ah, mas o médico decide". Opa! Não, tu estás passando pra ele a decisão. Foram vistas todas as possibilidades e impossibilidades por um só? Não, isso tem que ser por equipe, que vai analisar, verificar e chegar a uma conclusão, porque a responsabilidade não é só dela, mas de todos.

\section{E casos de estupro, por exemplo?}

A mesma coisa, por que que acontecem os estupros? Novamente a mídia fantasia tudo. "Ah, mas acontece porque o sujeito que estuprou tinha um problema mental" Opa! O problema mental tu não decides e analisas e tem sua solução em cinco segundos. "Ah, mas ele está acostumado a fazer isso, ele se masturba no ônibus..." Alguma coisa está mal com ele, como ser humano, ele precisa de atenção. Nós temos programas para isso? Nenhum, não temos nada. Isso é problema individual, problema teu. Nas grandes rodas é tratado "feche a boca". E na roda pequena do boteco de esquina é uma bomba. Por que que o sujeito comete o estupro? Por que ele induziu a vítima a alguma coisa? Porque ele tem algum problema sério, ele é o primeiro a ser tratado. "Ah, mas a mulher não precisa ter esse filho". Quem é que vai ser o pai e a mãe deles? O Estado? Quem é o Estado? [...] Então não adianta eu atirar o problema para fora, eu tenho que ver como é que eu vou amparar. O sujeitinho tá precisando de uma atenção, a criança tá precisando de atenção e a mãe também, a futura mãe. Tem que ver programa pra isso, se você vai ver, onde estão esses programas? Não existem e sequer se discute isso aqui dentro. Eventualmente numa sala de aula vem um cara dizer um monte de coisa como eu estou te dizendo aqui, assim, e fica por isso mesmo, ou seja, não há uma discussão aprofundada da questão. Nós somos "opiniáticos", nós damos opiniões, agora eu tô te falando em função da vivência profissional com crianças, com jovens, com gente já sofrendo penalidades da justiça, aquela turma dos quinze, dezesseis, dezessete, dezoito anos.

\section{E movimentos sociais?}

Uma coisa interessante sobre movimentos sociais, isso foi mais ou menos em 1962. Houve um cara, um nordestino fantástico, chamado Dom Hélder Câmara. Ele sugeriu à igreja no Brasil um plano de emergência, eu li esse plano todinho em 62 [1962]. Acho que em 63 ou 69 [1963 ou 1969], eu fui convidado por um sociólogo da universidade federal para entrar num programa da CNBB, Conferência Nacional dos Bispos do Brasil do regional aqui do Sul. Ele disse "Nós temos um trabalho de estatística religiosa e tu podia nos ajudar nisso", e começou a vir os planos de pastoral orgânica no país. A igreja começou a pensar de maneira planejada, por causa do Dom Hélder Câmara [...]. No sentido de haver uma preocupação social na igreja, mas não uma coisa organizada, com educação, com todo um processo que fizesse com que as pessoas abrissem caminhos diferentes. Nisso eu acho que a igreja católica teve uma visão dentro do início do Concílio do Vaticano aqui no Brasil, numa posição de vanguarda. Hoje, voltou à estaca zero. Nesse período começaram a surgir aqui no Rio Grande do Sul grupos de base popular do interior. Aqui de Porto Alegre também sabiam que existiam entidades na Europa, que prestavam auxilio financeiro, então eles pediam: "Nós temos um trabalho aqui com criança, com isso, com aquilo, com agricultores... e nós precisamos de 'tantos' reais 
para fazer a continuidade do trabalho". Mas eles de lá mandavam pra CNBB Nacional, onde havia uma entidade que se chamava CERIS, Centro de Estatística Religiosa e Investigação Social. Não era pra investigar, era pra fazer pesquisa... e faziam pesquisa. Fiquei uma semana com eles lá, foi um espetáculo. De lá da Europa vinha um conjunto de perguntas, eles sentavam em equipe - por isso que eu digo que a equipe é o negócio. Eu chegava e fazia mais perguntas. Marcava e ai eu ia conhecer os movimentos. Movimentos rurais, movimentos de sem-terra, movimentos urbanos. Então a gente ia para lá e falava: "Pessoal, vamos conversar sobre isso? Eu vou fazendo as perguntas e nós vamos conversando". Muitas vezes, teve momentos que o pessoal dizia assim: "Essas perguntas que vocês estão nos fazendo, nós já devíamos ter feito pra nós mesmos". Ou seja, o aspecto educativo do movimento estava transparecendo, não era aspecto político, de lutar contra. E mais, isso encostou em outras coisas que também existiam aqui desde 63, 64 [19631964]. Apareceram os chamados movimentos comunitários, maiores. Alguns deles não prosperaram porque eram gente de mais dinheiro, então sabe como é, eles não se entendem... Mas teve um que foi um movimento comunitário de ljuí, acompanhado pelos padres capuchinhos. Eu fui lá muitas vezes e tinha diferentes movimentos. Por exemplo, a poucos quilômetros tinha Santo Ângelo, que é uma região missioneira, tinha outra forma de fazer as coisas, então foi encontrando diferentes visões de movimentos. Só que eu entrei nesses movimentos primeiro pela igreja, mas por uma visão de assistente social com o pessoal da sociologia junto, pessoal da ciência política, já mais com a ideia de fazer as cabeças, de ver como é que eles poderiam continuar nesse processo. Só pra ti teres uma ideia, o movimento comunitário de ljuí acabou criando a Fidene [Fundação Integração, Desenvolvimento e Educação do Noroeste do Estado], hoje a Unijuí. Foi um dos movimentos que foi longe, porque eles tiveram gente lá, buscavam dinheiro fora, temos que guardar a questão da educação. A minha tese foi exatamente sobre isso.

\section{Interessante!}

Sobre esses movimentos e sobre o que a gente ia fazer sobre o ponto de vista de educar, foi aí que eu descobri o processo da educação e pedagogia social, como isto podia ser feito e tinha volta para o próprio $\mathrm{S}=$ serviço $\mathrm{S}=$ social. Porque o social tinha a presença da psicologia, da sociologia, da ciência política, mas não tinha nada da pedagogia social. Não tinha nada! Então eu fiz isso, exatamente por ai eu fiz o trabalho, porque eu pensei: "Eu vou trazer de baixo para cima a coisa, de tal maneira que quando se falar em serviço social, se fale também no aspecto pedagógico do serviço social". [...] Porque isso não era nítido, até 2000 não era nítido. Exatamente em função desses movimentos. Claro, são sim politizados, deram razão a partidos políticos. Mas minha ideia básica é isso, é muito fácil, porque tu bates de frente com o status quo. O problema é como tu, num processo educativo, vais marcando presença, sabendo que nesse processo educativo tem a parte econômica, tens que saber trabalhar com isso. A parte política, os partidos também querem entrar. E como é que tu consegues sobrepujar isto fazendo com que as gerações que vêm vindo aprendam uma nova visão de mundo e não fiquem ali fechadinho na sua cidade?

\section{Por meio dessa dimensão educativa...}

Exatamente. [...] Assim como a escola é muito fechadinha, muito quadradinha, não te prepara. E pior é a educação moral e civica, nem se fala nisso. A escola é muito fechadinha e continua quadradinha também. Com exceção de algumas escolas que tiveram experiências de Montessori, experiências de alguns críticos franceses, aqui no Sul que continua até hoje fazendo isso. Mas a escola de hoje é um negócio fechadinho, infelizmente é assim. Enquanto a escola for assim, fica difícil, agora, quando a escola se abrir para seu entorno, ser realmente um centro de convergência, um centro de ir de encontro a um povo, as coisas mudam, mas isso é difícil porque o governo não permite. Ou nós rompemos isso - 
não de uma maneira juvenil, brigando, fazendo quebra-quebra, porque essa é a parte juvenil do processo - ou nós trabalhamos com perspectiva de tempo. O movimento tem um periodo de duração, por isso que ele é um movimento. Depois ele se estabiliza e torna-se uma entidade, uma organização, alguma coisa... mas tem que ser alguma coisa que faça efeito.

Jorge, está sendo um prazer te ouvir, muito bom mesmo! Nem estamos utilizando o roteiro que elaborei. Mas a última pergunta que quero fazer abrange um pouco sobre tudo que falamos, especialmente em relação a tua perspectiva sobre a profissão, sobre o Serviço Social. Como você se coloca nela e o que compreende sobre o direcionamento político do serviço social hoje, que se dirige à construção de uma nova sociabilidade, filiada à corrente teórica marxista? Quero te ouvir um pouco sobre isso, pra gente fechar a entrevista.

Aí vem novamente um dos primeiros momentos dentro da universidade, dentro do curso. A gente teve a possibilidade de conhecer, pelos professores e pelas aulas, diferentes perspectivas. Teve por exemplo um momento em que se estudou Marx, lendo na íntegra, não o que se escreve depois, mas a essência da coisa. Porque depois de Marx vem todos os partidos politicos que fizeram uma leitura disso tudo que a gente até certo ponto põe um ponto de interrogação. A visão existencialista também. A visão chamada cristã. [...] Essas coisas todas, inúmeros grupos e linhas de pensamento, estudiosos da questão.

\section{Está falando de sua formação aqui na PUCRS?}

Sim, minha formação foi aqui na PUCRS, por isso que eu digo, os professores deram os caminhos. Pelo menos três, quatro caminhos existem. Depois eu fiz minha especialização, depois de 10 anos, de pé no chão. Fiz mestrado mais 10 anos, de pé no chão, e o doutorado mais 10 anos. Ou seja, eu levei 30 anos caminhando, não parei. Eu acho que hoje a turma está começando muito nova [...]. Eu com tudo que tive, sabia que estava frouxo das pernas. Mas tudo bem, eu acho que faz parte de uma época.

\section{A tua formação foi feita em vários momentos da história do serviço social então.}

Claro! Da história, do contexto social, do contexto político, do país, do mundo. Então eu tive professores em cada época que me davam essa perspectiva e nunca disseram: "Não, isso aí não!". O marxismo lido na sua íntegra, o existencialismo de Sartre, a visão neocristã, de Medellín, essas coisas todas que é da igreja, do conselho Vaticano. Porque isso aqui é católico, então tem que alguém saber isso aqui. Agora que eu estou estudando toda a reforma protestante. Tem que saber essas linhas que dirigem, são presentes no mundo. Eu acho que essas linhas todas, devem ser estudadas na sua raiz. Tu vais ter neomarxistas, os movimentos franceses, os movimentos italianos de Gramsci. Calma! Se tu não lês essa origem, tu ficas perdido no tempo e no espaço. Tem que sempre começar do início das coisas e ir paulatinamente correndo esses caminhos. Se o serviço social faz isso na intenção de articular-se com outras áreas formativas, perfeito. Só que essa segunda etapa não está acontecendo, nós continuamos conversando sozinhos, conosco mesmo, isso é muito perigoso. Eu acho que o colega do Direito pode estar estudando Marx e até de uma maneira... "Mas não pode haver Direito". Claro que pode! A visão da dialética, ele não inventou. Tem antes outra gente que falou sobre isso, então eu tenho que, pelo menos, começar a entender isto. Existe uma lógica formal, existe uma forma dialética. Se eu começo a entender isto, eu posso aos poucos chegar a contribuir na minha área profissional, senão eu estou fazendo pura e simplesmente o: "Todo mundo tem que pensar como eu".

\section{Você vê isso no Serviço Social}

Olha, durante o tempo que eu estive no Conselho Federal e depois no contexto latino-americano, de um modo geral foi muito isso. Um 
certo entusiasmo juvenil, muito pela pressão das coisas externas que estavam deixando a gente louco. Você tem que sair disso. "Ah, mas nós temos que ter mártires". Isso é uma palavra bonita, mas não é assim. Eu tenho que ter gente que saiba politicamente encontrar com outros na saída e não seja prepotente. Que saiba encontrar saidas, sim! Porque as saídas não são para mim sozinho. "Na empresa não dá pra fazer nada". Calma, tem muitos tipos de empresa. "O estado é uma bomba", calma, eu fico um pouquinho preocupado com isso... realmente não é preocupado, é solícito, porque preocupação é doença. Eu fico solícito. "Ah, mas não podemos esperar". Isso já diziam no tempo da Revolução Francesa. Se você ler Os Miseráveis, de Victor Hugo, você vai ver que a coisa é igual. Mas não é sempre a mesma coisa, ela muda e eu tenho que estar muito atento a essas mudanças para poder ter respostas de acordo, senão eu estou dando respostas antigas para coisas novas. Isto a gente corre o risco e fica engessado. O partido político no Brasil, não estuo falando no Partido Republicano ou Democrata americano. Isso é outra questão, é outra história, é outra cultura. Os nossos partidos políticos infelizmente são muito engessados e não têm proposta, ficam falando "Tem que fazer..." Tem que fazer o quê? Coligação, olha com que eu faço coligação. Eu não posso me abraçar num sujeito que enfia a faca nas costas. [...].

Jorge, foi um prazer te entrevistar e ter essa conversa contigo nessa tarde. Muito obrigada! A gente passou um pouquinho do horário e tu deves estar bem exausto, mas pra mim foi um prazer enorme te ouvir. [...] Acho que pesquisa é isso, muita troca. Para mim, foi muito bom trocar contigo hoje!

Troca! É um intercâmbio fantástico, não é uma coisa fechadinha dentro do laboratório não. Obrigado!

\section{Suéllen Bezerra Alves Keller}

Doutora em Serviço Social pelo Programa de Pós-Graduação em Serviço Social da Pontifícia Universidade Católica do Rio Grande do Sul (PUCRS), em Porto Alegre, RS, Brasil; assistente social judiciária no Tribunal de Justiça do Rio Grande do Sul (TJRS), em Viamão, RS, Brasil.

\section{Endereço para correspondência}

Suéllen Bezerra Alves Keller

Fórum da Comarca de Viamão/RS

Av. Bento Gonçalves, 90, $6^{\circ}$ andar, sala 607

Tarumã, 94435-000

Viamão, RS, Brasil 